\section{Hedge Pruning Pecan}

\author{
Bruce W. Wood ${ }^{1}$ and \\ Deane Stahmann ${ }^{2}$
}

\begin{abstract}
ADDITIONAL INDEX WORDS. alternate bearing, irregular bearing, flowering, profit, yields, production, quality, Australia, pruning, hedging, topping, mechanical hedging
\end{abstract}

\begin{abstract}
Summary. An ever increasing cost:price squeeze on the profitability of pecan (Carya illinoinensis) farming is driving a search for alternate husbandry approaches. 'Wichita' and 'Western' trees maintained at relatively high tree population density, by mechanized hedge pruning and topping, produced greater nut yield than an orchard treatment in which tree population density was reduced by tree thinning ( $144 \%$ for 'Wichita' and $113 \%$ for 'Western Schley'). Evaluation of three different hedge pruning strategies, over a 20-year period, identified a discrete canopy hedge pruning and topping strategy using a 2-year cycle, as being superior to that of a discrete canopy hedge pruning and topping strategy using an 8-year cycle, but not as good as a continuous canopy hedge pruning and topping strategy using a 1 -year cycle. An evaluation of 21 commercial cultivars indicated that nut yields of essentially all cultivars can be relatively high if properly hedge pruned [annual in-shell nut yields of 2200 to $3626 \mathrm{lb} /$ acre $(2465.8$ to $\left.4064.1 \mathrm{~kg} \cdot \mathrm{ha}^{-1}\right)$, depending on cultivar]. Comparative alternate bearing intensity and nut quality characteristics are reported for 21 cultivars. These evaluations indicate that pecan orchards can be highly productive, with substantially reduced alternate bearing, when managed via a hedgerow-like pruning strategy giving narrow canopies [3403 lb/acre (3814.2 $\mathrm{kg} \cdot \mathrm{ha}^{-1}$ ) for 'Wichita' and 3472 lb/acre $\left(3891.5 \mathrm{~kg} \cdot \mathrm{ha}^{-1}\right)$ for 'Western Schley']. North-south-oriented (N-S) hedgerows produced higher yields that did east-west $(\mathrm{E}-\mathrm{W})$ hedgerows (yield for N-S 'Wichita' was 158\% that of $\mathrm{E}-\mathrm{W}$ trees and N-S 'Western Schley' was $174 \%$ that of E-W trees).
\end{abstract}

${ }^{1}$ United States Department of Agriculture, Agricultura Research Service, Southeastern Fruit and Tree Nut Research Laboratory, Byron, GA 31008-0087. Corresponding author; e-mail bwwood@saa.ars.usda.gov.

${ }^{2}$ President, Stahmann Farms Australia, Stahmann Farms Australia, Toowoomba, Queensland, Australia 4350.
These data indicate that mechanized hedge pruning and topping offers an attractive alternative to the conventional husbandry paradigm.

\section{$\mathrm{T}$} he conventional pecan (Carya illinoinensis) husbandry paradigm allows grafted trees to grow naturally, with little or no canopy manipulation beyond central-leader training soon after planting (Wood, 1999). Tree growth therefore results in 1) excessive inter- and intra-tree shading, 2) alternate bearing, and associated yield problems, 3 ) reduced ability to control foliar feeding pests, 4 ) need to minimize biotic and abiotic stresses, 5) susceptibility to limb breakage, 6) long-term gaps in orchards when trees die or are removed, and 7) tall trees. Tree growth, and subsequent encroachment, requires two or three distinct temporal phases of tree orchard thinning by tree removal-leaving few trees per unit area and excessive intertree spacing for much of the life of the orchard.

A pecan husbandry paradigm shift is becoming increasingly likely in the U.S. due to a cost:price squeeze that is causing farming operations to be unprofitable (Wood, 1999, 2001). Alternate bearing and associated fluctuations in production, quality, availability, price, and revenue are key factors contributing to this squeeze (Amling et al., 1975). Alternate bearing is the economically most important biological problem of pecan husbandry (Amling and Amling, 1983). This phenomenon is functionally controlled at two key levels - inhibitors of floral development during the previous growing season, and by available energy reserves near the time of bud break (Wood et al., 2003). Both steps are potentially influenced by maintenance of foliar health (Worley, 1979a, 1979b; Wood et al., 2003) and an equilibrium in fruit:leaf area ratio (Smith and Gallot, 1990; Smith et al., 1993; Wood 1995). Attempts to mitigate alternate bearing have led to cultural practices that extend canopy health and reduce fruit:leaf ratios in on crop years. Currently available tools for fruit:leaf ratio manipulation include mechanical fruit thinning, selective limb pruning, and mechanized hedge-type pruning (Smith and Gallot, 1990; Smith et al., 1993; Wood 1995).

A pecan production paradigm was introduced in the 1970s that relied on mechanical hedge-type pruning and topping for reducing orchard crowding and alternate bearing problems (Malstrom, 1981; Malstrom and Haller, 1980; Smith and Hinrichs, 1980; Worley, 1985). These hedge pruning strategies embraced relatively longcycle pruning approaches-where canopy faces were recut 4 to 8 years after the initial cut — and included topping of tree canopies relatively close to the ground. The paradigm was largely abandoned due to substantially reduced nut yields by trees and orchards. Low yields are attributed to a combination of factors, including excessive canopy removal, extreme vegetativeness, and intra-canopy shading. Results led to the tenet that pecan innately fails to respond favorably to hedge pruning, with insufficient lateral bearing being construed as a key contributing factor. Conversely, mechanized canopy manipulation strategies, such as mechanical hedge pruning and topping, have proven laudable in certain husbandry niches of deciduous tree crops. However, hedge pruning is beginning to increase in popularity with 'Wichita' and 'Western Schley'. These two are among the most common pecan cultivars in the world, especially in arid or semiarid regions.

A dearth of published information on short-cycle hedge pruning strategies for pecan, and how commercial cultivars respond, is handicapping the economic fitness of mid to large size pecan farming operations. We report 1) a comparison of three distinct hedge pruning strategies on long-term nut yields by a commercial orchard enterprise, 2) a comparison of long-term yield characteristics of several cultivars under hedge pruned conditions, 3) a comparison of flowering characteristics of hedge-pruned cultivars, and 4) documentation of realized unit area nut yield under commercial orchard conditions.

\section{Materials and methods}

Orchard characteristics. The study orchard was in northern New South Wales near Moree, Australia (lat. $\approx 29^{\circ} \mathrm{S}$ ). The orchard was at an elevation of $700 \mathrm{ft}(213.4 \mathrm{~m})$ in a peninsula of deep $[\approx 30 \mathrm{ft}(9.1 \mathrm{~m})]$ alluvial clay loam soil surrounded by the Gwydir River as it exits the foot hills of the Great Dividing Range. Soil characteristics were: cation exchange capacity 
(CEC) of $23 \mathrm{meq} / 100 \mathrm{~g}$, $\mathrm{pH}$ of 6.6, soluble salts of $0.33 \mathrm{mmhos} / \mathrm{cm}$, organic matter of $2.4 \%$, nitrate nitrogen at $6 \mathrm{ppm}\left(\mathrm{mg} \cdot \mathrm{kg}^{-1}\right)$, phosphorus $(\mathrm{P})$ at $53 \mathrm{ppm}$, potassium (K) at $389 \mathrm{ppm}$, magnesium $(\mathrm{Mg})$ at $733 \mathrm{ppm}$, calcium (Ca) at $2989 \mathrm{ppm}$, sulfur (S) at $7 \mathrm{ppm}$, zinc $(\mathrm{Zn})$ at $5 \mathrm{ppm}$, manganese $(\mathrm{Mn})$ at $48 \mathrm{ppm}$, copper $(\mathrm{Cu})$ at $3 \mathrm{ppm}$, iron $(\mathrm{Fe})$ at $45 \mathrm{ppm}$, boron (B) at 0.7 $\mathrm{ppm}$ and sodium $(\mathrm{Na})$ at $50 \mathrm{ppm}$. The orchard was located in the BShw climatic type-a subtropical steppe with a dry winter season (Trewartha, 1968). Specific climatological characteristics representative of the location are detailed in Table 1. The growing season was 260 to $270 \mathrm{~d}$ and dormant season chilling hours ranged from 400 to 600 . Pecan bud break was in late September to early October, with leaffall May-June.

Data are from an 1850 acre (748.7 ha) commercial pecan operation (Trawalla Farm, Stahmann Farms, Moree, Australia). Trees were generally configured in 40-acre (16.2-ha) blocks [ranging from $\approx 10$ to 40 acres $(4.0$ to 16.2 ha)]. Most of the 49 blocks were planted on a $33 \times 33-\mathrm{ft}(10.1-\mathrm{m})$ square spacing and were either 'Wichita' or 'Western Schley' propagated to 'Riverside' seedling rootstocks (one-third planted in each of 1971, 1972, and 1973). Thus, within each of the 40 -acre blocks, each tree row occupied 1 acre (0.4 ha) of orchard space. Blocks were configured such that rows alternated between 'Wichita' and 'Western Schley'-except for the cultivar trial block. Because the two main cultivars ('Western Schley' and 'Wichita') depend on each other for cross-pollination, the $1: 1$ pattern ensures against yield loss due to poor cross-pollination and xenia (due to self-pollination). Trees are flood irrigated, with fields having a fall of 15 inches per quarter mile $\left(94.7 \mathrm{~cm} \cdot \mathrm{km}^{-1}\right)$ and panels every 10 rows $[330 \mathrm{ft}$ ( 100.6 $\mathrm{m})$ ]. Irrigation was by soil moisture based on neutron probe measurements, typically resulting in $\approx 15$ irrigations per growing season (i.e., usually from late December through February, with irrigation interval varying from 7 to 14 $\mathrm{d}$, depending upon need).

Trees were generally only fertilized with $\mathrm{Zn}$ (as four to six foliar sprays after bud break), $\mathrm{N}$ (urea in irrigation water), and occasionally with gypsum (to assist water penetration). Urea-N was applied at $100 \mathrm{lb} /$ acre (112.1 $\mathrm{kg} \cdot \mathrm{ha}^{-1}$ ) as the base treatment, regardless of crop load; with subsequent applications of $\mathrm{N}$ at $40 \mathrm{lb} /$ acre $(44.8$ $\left.\mathrm{kg} \cdot \mathrm{ha}^{-1}\right)$ per $500 \mathrm{lb}(226.8 \mathrm{~kg})$ of anticipated production in excess of 1000 $\mathrm{lb} /$ acre $\left(1120.8 \mathrm{~kg} \cdot \mathrm{ha}^{-1}\right)$. One-fourth of the estimated $\mathrm{N}$ was applied at bud break and the balance over three other applications, with the last at the early stages of kernel filling. $\mathrm{N}$ was applied at $\approx 20 \mathrm{lb}$ actual $\mathrm{N}$ per application per acre $\left(22.4 \mathrm{~kg} \cdot \mathrm{ha}^{-1}\right)$ from budbreak until shuck split, with the number of applications depending on crop load. Typical leaf nutrient concentrations were: $2.82 \% \mathrm{~N} ; 0.13 \% \mathrm{P} ; 0.74 \% \mathrm{~K} ; 1.71 \%$ Ca; $0.65 \% \mathrm{Mg} ; 0.15 \% \mathrm{~S} ; 0.01 \% \mathrm{Na} ; 7$ ppm Cu; 91 ppm Zn; 925 ppm Mn; $64 \mathrm{ppm} \mathrm{Fe} ; 31$ ppm B; and 0.15 ppm molybdenum (Mo).

The orchard was free of foliar diseases, but sometimes encountered a problem with shuck decline [apparently a crop load stress related fungal disorder (Reilly, 1996; Reilly and Wood, 1995; Sparks et al., 1995)] on 'Western Schley'. Twig girdlers ( $M a$ roga melanostigma) and stink bugs (Nezara viridula) were controlled by biological methods but leafhoppers (Empoasca fabae) and longhorn borers (Agrianome spinicollis) were not controlled.

Relative response of 'Wichita'
AND 'Western Schley' to hedge PRUNING. Trees were largely nonpruned until 1981 and only occasionally pruned until 1987 (age 15 years). From 1981 (age 9 years) until 1987 (age 15 years) trees were on an 8 -year discrete canopy hedge pruning program (DCHP/8) [i.e., one of the four cardinal faces was mechanically pruned (rotating around the tree) every second year]. Canopies were also roof-topped at $33 \mathrm{ft}$ on the hedged side of the tree $(\mathrm{DCHP} / 8+\mathrm{T} /$ $8)$. In the dormant season between age 15 and 16 years, trees were converted to a $\mathrm{DCHP} / 2+\mathrm{T} / 2$ treatment-involving hedge pruning and topping on a 2-year cycle in which portions of the tree canopy were pruned (opposite sides of canopy plus opposite sides of pyramidal top) annually. Thus, sides and tops were on a 2 -year pruning cycle. Initial and recurrent cuts were made $11 \mathrm{ft}(3.4 \mathrm{~m})$ from row center and the pyramidal topping cut made at a $45^{\circ}$ angle to give a peak at $33 \mathrm{ft}$. The side cuts were made inward at $5^{\circ}$. Pruning produced a roughly $22-\mathrm{ft}$-wide $(6.7-\mathrm{m})$ square-like tree with a pyramid-like top peaking at $33 \mathrm{ft}$. By the end of the first year after hedging the $1 \mathrm{lft}$ of foliage free space between adjacent hedged trees had typically closed to $5 \mathrm{ft}$ (1.5 $\mathrm{m})$ and to $\mathrm{l} \mathrm{ft}(0.3 \mathrm{~m})$ by the end of the second year just prior to initiation of the next cycle of hedge pruning. Tree cultivars were 'Wichita' and 'Western Schley' in alternating rows (1:1 arrangement).

As a commercial orchard operation, the layout of the various treatments did not meet standard analysis of variance criteria, thus data were analyzed via resampling techniques using either bootstrap or permutation sampling strategies (Blank et al., 2001). In the case of this specific study, treatments were 'Western Schley' versus 'Wichita'. There were ten

Table 1. Climatological summary for Trawalla Orchard, Moree, New South Wales, Australia. ${ }^{\mathrm{z}}$

\begin{tabular}{|c|c|c|c|c|c|c|c|c|c|c|c|c|c|}
\hline$\underline{\text { Parameter }}$ & Jan. & Feb. & Mar. & Apr. & May & June & July & Aug. & Sept. & Oct. & Nov. & Dec. & Annual \\
\hline Mean daily maximum temperature $\left({ }^{\circ} \mathrm{C}\right)$ & 33 & 33 & 31 & 27 & 22 & 18 & 17 & 19 & 23 & 27 & 30 & 33 & 26 \\
\hline Mean days over $30^{\circ} \mathrm{C}(\mathrm{d})$ & 26 & 23 & 20 & 4 & 0 & -- & --- & 0 & 2 & 7 & 16 & 24 & 122 \\
\hline Mean daily minimum temperature $\left({ }^{\circ} \mathrm{C}\right)$ & 20 & 20 & 17 & 13 & 9 & 6 & 4 & 5 & 8 & 13 & 16 & 18 & 12 \\
\hline Mean days below $0^{\circ} \mathrm{C}(\mathrm{d})$ & --- & --- & --- & --- & 0 & 2 & 6 & 3 & 0 & -.- & --- & --- & 11 \\
\hline Mean 0900 HR relative humidity (\%) & 59 & 62 & 58 & 60 & 71 & 78 & 76 & 70 & 60 & 54 & 52 & 55 & 63 \\
\hline Mean $1500 \mathrm{HR}$ relative humidity (\%) & 34 & 37 & 35 & 36 & 44 & 47 & 48 & 42 & 35 & 32 & 30 & 30 & 37 \\
\hline Mean daily pan evaporation $(\mathrm{mm})$ & 9 & 8 & 7 & 5 & 3 & 2 & 2 & 3 & 5 & 7 & 9 & 10 & 6 \\
\hline Mean daily sunshine $(\mathrm{h})$ & 10 & 10 & 10 & 9 & 7 & 7 & 7 & 8 & 9 & 9 & 10 & 10 & 9 \\
\hline Mean clear days $(\mathrm{d})$ & 10 & 8 & 12 & 13 & 11 & 11 & 13 & 13 & 14 & 12 & 11 & 11 & 38 \\
\hline Mean cloudy days (d) & 6 & 5 & 4 & 5 & 7 & 6 & 5 & 4 & 4 & 5 & 5 & 5 & 63 \\
\hline Mean monthly rainfall (mm) & 76 & 69 & 49 & 37 & 46 & 27 & 46 & 37 & 32 & 45 & 57 & 67 & 586 \\
\hline Mean rain days $(\mathrm{d})$ & 8 & 6 & 5 & 5 & 6 & 6 & 7 & 6 & 6 & 7 & 7 & 8 & 78 \\
\hline
\end{tabular}

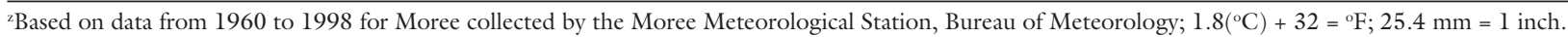


40-acre blocks of trees, with each block consisting of alternating rows of 'Western Schley' and 'Wichita' growing in a uniform environment $(\approx 794$ trees per cultivar per block). Treatment and block yields were replicated over time (17 years). Because of the alternate bearing characteristic of blocks (block yields being correlated), the resampling technique used the permutation (i.e, shuffling; or sampling without replacement) approach for resampling with 10,000 iterations and the hypothesis tested at $P=0.10$.

INFLUENCE OF ORCHARD THINNING. Excessive intertree shading, orchard crowding, and unacceptable alternate bearing led to the eventual abandonment of this strategy and replacement with one of two different treatments implemented beginning in the 1988 and 1990 growing seasons [for the 1988 growing season]. One was a discrete canopy hedge and top pruning strategy that used a dormant season 2-year hedging and topping cycle (DCHP/2+T/2) as described above. The second was orchard thinning $(\mathrm{OT})$, in which tree removal increased orchard space allotment per tree. The DCHP $/ 2$ $+\mathrm{T} / 2$ treatment (1600 trees) was located in a 40-acre block adjacent to the OT treatment (1600 trees reduced to 800 trees per cultivar at age 18 years then reduced to 400 at 20 years; with tree removal occurring the previous dormant season). The OT treatment consisted of a 40 -acre block of trees in which $50 \%$ were removed in 1989 on the diagonal and $50 \%$ of the remainder removed in 1991 by taking out every other tree row-leaving 10 trees/acre (24.7 trees/ha). The number of trees in this treatment therefore declined $75 \%$ (from 1,600 to 400) after two tree removal phases. This orchard thinning approach reflects the conventional approach to solving crowded orchards. 'Wichita' and 'Western Schley' trees were configured on an alternating $1: 1$ row arrangement, as in the $\mathrm{DCHP} / 2$ $+\mathrm{T} / 2$ treatment. In-shell nut yields for both treatments were kept separate for each cultivar in each block over the life of the study (age 18 to 25 years). Blocks were twice-over harvested in the fall with a mechanical harvester. The alternate bearing index (I) of 'Wichita' and 'Western Schley' was calculated using the method of Pearce and Dobersek-Urbanc (1967).

The experiment was a factorial design consisting of two cultivars
('Wichita' and 'Western Schley') and two orchard treatments (hedge pruning versus orchard thinning). Treatments and blocks (40 acres) were replicated over time (8 years). Main effects and interactions were tested using resampling techniques employing bootstrapping with the hypothesis being tested at 10,000 iterations for determination of confidence limits at $P=0.05$. Treatment plots were in a uniform soil and microclimatic environment.

Comparison of yields between DISCRETE AND CONTINUOUS HEDGE PRUNING SYSTEMS. Beginning in 1988 (age 12 years), two distinctly different hedge pruning treatments were compared for both 'Wichita' and 'Western Schley'. These were discrete canopy hedge plus top pruning $(\mathrm{DCHP}+\mathrm{T})$ and continuous canopy hedgerow plus top pruning (CCHP + T; also known as pancaking). Both treatments used a mechanized hedge pruner during the dormant season. The $\mathrm{DCHP} / 2+\mathrm{T} / 2$ treatment was as described above. The CCHP $+\mathrm{T}$ treatment consisted of hedging such that the row-facing sides were hedged on a l-year cycle (both sides each year) (i.e., CCHP $/ \mathrm{l}+\mathrm{T} / \mathrm{l}$ ). The initial side cut was made $3 \mathrm{ft}(0.9 \mathrm{~m})$ from row center with subsequent cuts at $4 \mathrm{ft}(1.2 \mathrm{~m})$, at a $5^{\circ}$ angle. Trees were roof-topped at $45^{\circ}$ angle at $33 \mathrm{ft}$ on a 1 -year cycle. The pruning produced a rectangular (with a peak) canopy $8 \mathrm{ft}$ $(2.4 \mathrm{~m})$ thick at the base and $\approx 30 \mathrm{ft}$ $(9.1 \mathrm{~m})$ wide, with a height of $\approx 33 \mathrm{ft}$. Because tree canopies were cut only on the two row-facing sides, within-row facing branches encroached over time to produce a quasi-contiguous hedgerow-like canopy wall running mostly $\mathrm{E}-\mathrm{W}$. The two cultivars were planted in an alternating $1: 1$ row configuration. Yield measurements were taken from 1994 (age 18 years; beginning the fourth year after beginning CCHP/ $1+\mathrm{T} / 1$ hedging) to 1999 (age 23 years). The individual plots from which in-shell yields were derived consisted of $>12$ acres ( 4.9 ha) of trees. Thus, there were two pruning strategies on each of two cultivars, with yields taken over a 6-year period. The two hedge pruning treatments were in two adjacent blocks. These blocks were at least 14 rows wide and 1/4 mile (402 $\mathrm{m}$ ) long (with rows of the two cultivars alternating across each block). In-shell nut yields and alternate bearing indexes were determined as described above for each cultivar treatment combination over the life of the study.

The experimental design was a factorial consisting of two cultivars ('Wichita' and 'Western Schley') and two pruning treatments (DCHP/2+ $\mathrm{T} / 2$ and $\mathrm{CCHP} / 1+\mathrm{T} / \mathrm{l})$. Treatments and blocks (40 acres) were replicated over time (6 years). Main effects and interactions were tested using resampling techniques employing bootstrapping with hypothesis testing at 10,000 iterations for determination of confidence limits at $P=0.10$.

INFLUENCE OF ROW DIRECTION ON NUT YIELD FROM HEDGEROW TREES. A portion of the trees previously grown under the DCHP $/ 2+\mathrm{T} / 2$ strategy were converted to the above described CCHP / 1 + T/ / strategy in 1997 (age 25 years). The variables studied were row orientation (N-S versus $\mathrm{E}-\mathrm{W}$ ) and cultivars ('Wichita' and 'Western Schley'). Treatments consisted of two row orientations and two cultivars. Each of the four experimental units consisted of 4.6 to 7.9 acres ( 1.86 to 3.20 ha) of trees (182 to 316 trees) in two adjacent blocks. Yield and nut quality characteristics were sampled over a 5-year period. Treatment plots were uniform in regards to soil characteristics and microclimatic environment. The experimental design was a factorial consisting of two cultivars ('Wichita' and 'Western Schley') and two row-direction treatments (N-S versus E-W). Treatments and blocks [4.6 to 7.9 acres of trees (182 - 316 trees)] were replicated over time (2 years). Main effects and interactions were tested using resampling techniques employing bootstrapping with hypothesis testing at 10,000 iterations for determination of confidence limits at $P=0.05$ for main effects and $P=$ 0.10 for interactions.

YieLd RESPONSE OF CULTIVARS TO HEDGE PRUNING. Yield related characteristics of several different cultivars were evaluated under the $\mathrm{DCHP} / 2+$ $\mathrm{T} / 2$ strategy outlined above. Cultivars evaluated were 'Apache', 'Cape Fear', 'Cheyenne', 'Chickasaw', 'Choctaw', 'Comanche', 'Delmas', 'Desirable', 'Forkert', 'Kiowa', 'Mohawk', 'Osage', 'Pensacola Cluster', 'Shawnee', 'Shoshoni', 'Sioux', 'Sumner', 'Stuart', 'Tejas', 'Western Schley', and 'Wichita'. Tree rows per cultivar were $1 / 4$ mile long, on a uniform soil, and therefore consisted of a linear row occupying 1 acre. Thus, yield characteristics for each 
cultivar were based on 1 acre of trees. Plot size was 20 acres (8.1 ha). Yield characteristics were measured for the 1992 to 1999 crop years. Characteristics included in-shell nut yield per acre, marketable meat yield per acre, percentage kernel, percentage of kernels in the premium, choice, or other grade categories, and number of nuts per pound (a conventional measure of nut size).

The experimental design consisted of 21 cultivar treatments. Treatments and blocks [ 1 acre of trees was replicated over time ( 8 years)]. Main effects were tested using resampling. A multiple range test of means was performed by sorting total yields for each cultivar in a descending manner, then calculating differences between the ranked pairs, then resampling these differences using bootstrapping with hypothesis testing at 10,000 iterations for determination of confidence limits at $P=0.05$.

\section{Results and discussion}

Relative response of 'Wichita' and 'Western Schley' to hedge PRUNING. Under the DCHP $/ 8+\mathrm{T} / 8$ strategy, average annual yield was 2359 $\mathrm{lb} /$ acre $\left(2644.0 \mathrm{~kg} \cdot \mathrm{ha}^{-1}\right)$ for 'Wichita' and $2589 \mathrm{lb} /$ acre $\left(2901.8 \mathrm{~kg} \cdot \mathrm{ha}^{-1}\right)$ for 'Western Schley' (Fig. 1). Maximum in-shell yields from the $48, \approx 20$-acre blocks (for each cultivar) was 7555 $\mathrm{lb} /$ acre $\left(8467.9 \mathrm{~kg} \cdot \mathrm{ha}^{-1}\right)$ for 'Wichita' and $600 \mathrm{lb} /$ acre $\left(6726.1 \mathrm{~kg} \cdot \mathrm{ha}^{-1}\right)$ for 'Western Schley'. Similarly, minimum in-shell block production was 100 $\mathrm{lb} /$ acre for 'Wichita' and $300 \mathrm{lb} /$ acre $\left(336.2 \mathrm{~kg} \cdot \mathrm{ha}^{-1}\right)$ for 'Western Schley'. This production reflects relatively good overall average annual in-shell yields, yet there was also substantial yield variability and extreme variation in marketable kernels. Thus, the orchards initially exhibited extreme alternate bearing, as is typical of most commercial pecan operations, regardless of location.

Substantial yield fluctuations became evident by age 11 years (data prior to age 10 years is not reported, but was relatively stable and increasing; observation by the junior author) (Fig. 1). A large crop by both cultivars at age 10 years initiated severe biennial cycling (a form of alternate bearing) that persisted for several years, necessitating a different pruning strategy. The $\mathrm{DCHP} / 8+\mathrm{T} / 8$ strategy used during this early phase of the orchard failed to satisfactorily mitigate alternate bearing.
It is noteworthy that even under excellent husbandry (plenty of sunlight, water, nutrients; and absence of the foliar feeding aphid and mite pests that are so common in pecan planting within the U.S., Mexico, and most other nations) the alternate bearing index (I) was relatively high during this early life-stage of the orchard (Fig. 2). The overall I value during this early period was 0.40 for 'Wichita' and 0.28 for 'Western Schley'; thus, production from 'Western Schley' was more stable than from 'Wichita'. These I values were higher than is desirable, although they are much lower than previously reported values from trees grown under non hedge-pruned conditions ( 0.56 to 0.65 for 'Western Schley' and 0.67 for 'Wichita') (Conner and Worley, 2000). Thus, the DCHP $/ 8+\mathrm{T} / 8$ strategy appears to have greatly reduced I for both cultivars.

An attempt was made to improve orchard performance by adopting the above described DCHP $/ 2+\mathrm{T} / 2$ pruning strategy from age 15 to 26 years. This 2 -year-cycle hedge-pruning strategy reduced alternate bearing magnitude from 0.40 to 0.28 for 'Wichita' and from 0.27 to 0.12 for 'Western Schley'-roughly reducing the intensity by half of that exhibited using the DCHP $/ 8+\mathrm{T} / 8$ strategy (index data not included). Mean in-shell yields for the two cultivars managed under the $\mathrm{DCHP} / 2+\mathrm{T} / 2$ pruning strategy were not statistically different at $P=0.10$. Mean in-shell yield for 'Western Schley' was $2859 \mathrm{lb} /$ acre (3204.5 $\left.\mathrm{kg} \cdot \mathrm{ha}^{-1}\right)$ [compared to $2589 \mathrm{lb} / \mathrm{acre}$ under the DCHP $/ 8+\mathrm{T} / 8$ pruning strategy-a $270 \mathrm{lb} /$ acre (302.6 $\mathrm{kg} \cdot \mathrm{ha}^{-1}$ ) increase ] and for 'Wichita' was $3173 \mathrm{lb} /$ acre $(3556.4$ $\left.\mathrm{kg} \cdot \mathrm{ha}^{-1}\right)$ [compared to $2359 \mathrm{lb} / \mathrm{acre}$ under the DCHP $/ 8+\mathrm{T} / 8$ strategy-an $814 \mathrm{lb} /$ acre $\left(912.4 \mathrm{~kg} \cdot \mathrm{ha}^{-1}\right)$ increase]. Similarly, average per annum in-shell yields for maximum individual plot 'Wichita' in-shell yield was $5732 \mathrm{lb} /$ acre $\left(6424.6 \mathrm{~kg} \cdot \mathrm{ha}^{-1}\right)\left[\mathrm{mini}^{-}\right.$ mum was $896 \mathrm{lb} /$ acre
(1004.3 $\left.\left.\mathrm{kg} \cdot \mathrm{ha}^{-1}\right)\right]$; maximum for 'Western Schley' was $4872 \mathrm{lb} /$ acre $\left(5460.7 \mathrm{~kg} \cdot \mathrm{ha}^{-1}\right)[$ minimum was 654 $\mathrm{lb} /$ acre $\left.\left(733.0 \mathrm{~kg} \cdot \mathrm{ha}^{-1}\right)\right]$.

Malstrom and Haller (1980) concluded that hedge pruning was feasible and merited usage as a management tool for pecan orchards based on its ability to increase light penetration into canopies and orchards (Malstrom, 1981). These data, from $\approx 1800$ acres (728.5 ha) of intensely managed trees over a 17 -year period under two different hedge pruning management systems, validate the feasibility of hedge pruning as an orchard management tool. It is noteworthy that while failing to eliminate alternate bearing, the $\mathrm{DCHP} / 2+\mathrm{T} / 2$ pruning strategy came much closer to doing so that did the longer-cycle DCHP /8 + T/8 strategy. It reduced I by $\approx 50 \%$ over the already relatively low I for the $\mathrm{DCHP} / 8+$

Fig. 1. In-shell nut yields of 'Wichita' and 'Western Schley' pecans over the life of a commercial orchard operation in northern New South Wales, Australia. Trees were on an 8-year hedge pruning cycle until age 15 to 20 years, at which time they received a form of discrete canopy hedging on a 2-year cycle. Data points each year are based on 49 blocks of nearly 40 acres (16.2 ha) each, thus representing about 900 acres (363.2 ha) of trees for each cultivar. Bars are standard errors. 1 $\mathrm{lb} / \mathrm{acre}=1.12 \mathrm{~kg} \cdot \mathrm{ha}^{-1}$.

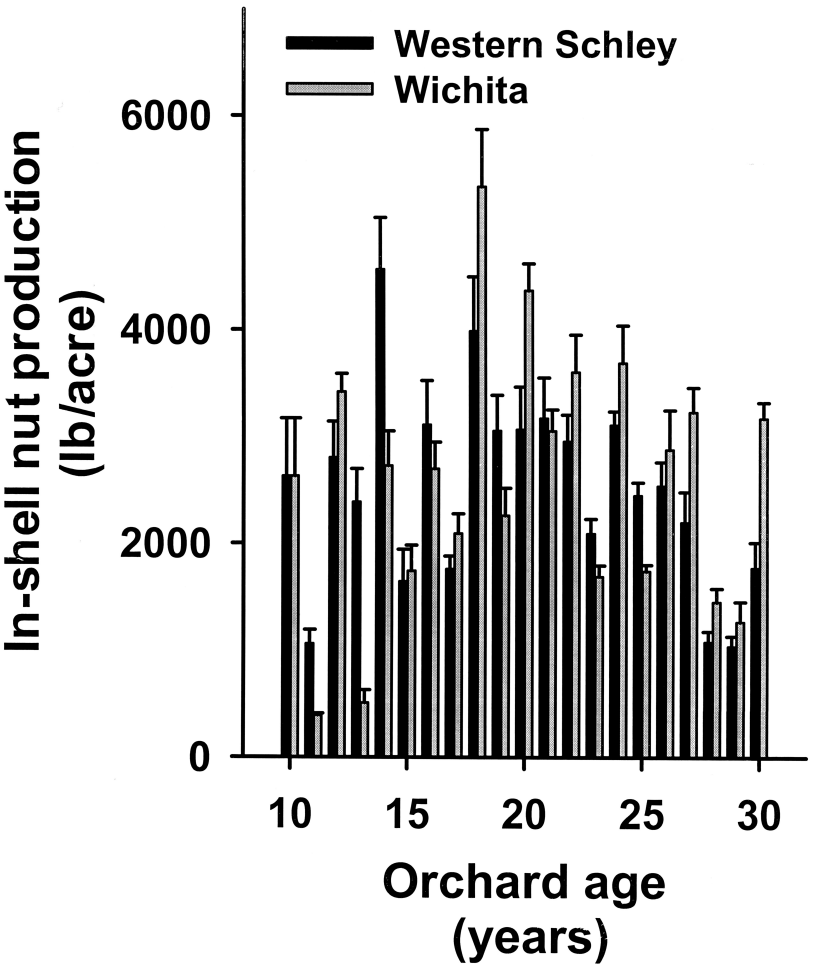




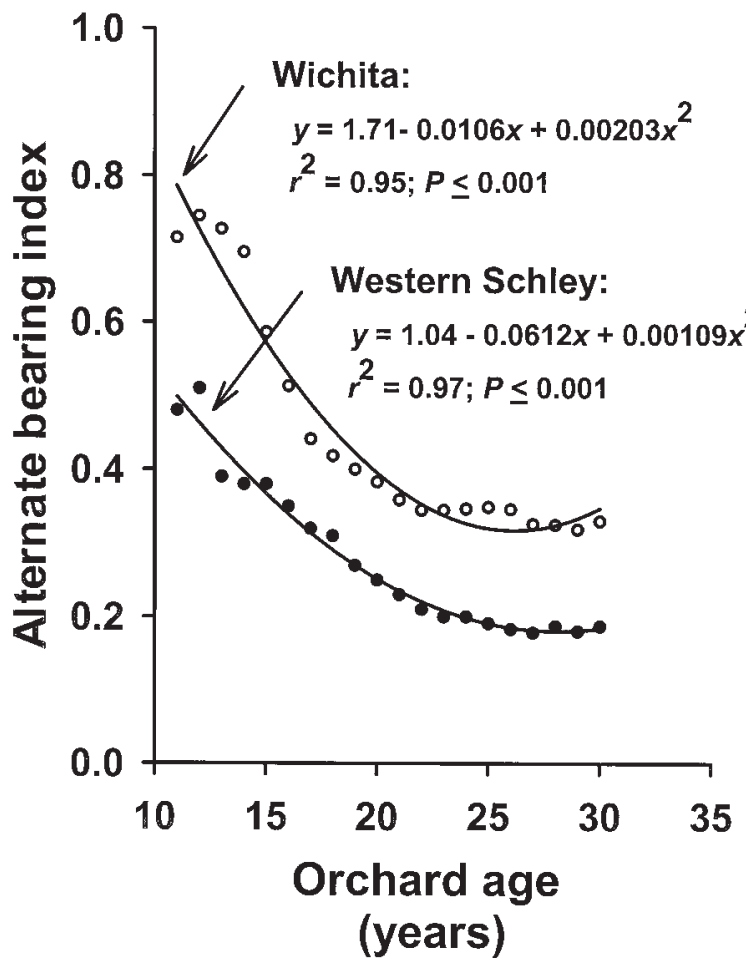

Fig. 2. Regression of alternate bearing index (I) of 'Wichita' and 'Western Schley' pecan trees on orchard age. Trees are those illustrated in Fig. 1.

$\mathrm{T} / 8$ treatment (as compared to Is of 0.65 and 0.67 previously reported for 'Western Schley' and 'Wichita', respectively; Conner and Worley, 2000). Thus the $\mathrm{DCHP} / 2+\mathrm{T} / 2$ strategy offers a horticultural management tool that can substantially mitigate alternate bearing.

The $\mathrm{DCHP} / 2+\mathrm{T} / 2$ strategy resulted in an average $10 \%$ in-shell increase in 'Western Schley' and a $35 \%$ increase in 'Wichita' yields (over consecutive 10-year periods) (Fig. 1). This yield increase is far more significant than first appears in that in the case of 'Western Schley' the $\mathrm{DCHP} / 2+\mathrm{T} / 2$ strategy also greatly increased percentage kernel (shellout) as well as the grade of marketable nuts (premium versus choice versus amber versus other; as observed by the junior author, data not included); thus, greatly enhancing crop value and profitability. Under DCHP $/ 2+\mathrm{T} / 2$ management, shellout was $\approx 61.7 \%$ for 'Wichita' versus $56.5 \%$ for 'Western Schley'; plus premium grade kernels was $\approx 78 \%$ for 'Wichita' versus $52 \%$ for 'Western'. It is noteworthy that in-shell 'Western Schley' yield was $110 \%$ of 'Wichita' during the $\mathrm{DCHP} / 8+\mathrm{T} / 8$ phase; but this advantage reversed in the $\mathrm{DCHP} / 2+$
T/2 phase with 'Wichita' producing $110 \%$ of 'Western Schley'. This provides evidence that cultivars may respond differently to different pruning strategies. The in-shell yield advantage of 'Wichita' over 'Western Schley', plus a $9.2 \%$ advantage in shellout and $50 \%$ advantage in percent premium kernels, identifies 'Wichita' as being much more profitable, at least at this orchard location, than 'Western Schley' (both have the same production cost).

The substantially greater profitability of 'Wichita' versus 'Western Schley', when managed using the $\mathrm{DCHP} / 2$ + $\mathrm{T} / 2$ strategy, implies that orchard profitability would have been much greater if it had contained more 'Wichita' and less 'Western Schley' trees. While the $1: 1$ ratio in alternating rows undoubtedly maximized the probability of cross-pollination, observations on cross-pollination in pecan orchards (Marquard, 1988; Wood, 1997; Wood and Marquard, 1992) indicate that orchard profitability could have likely been greater with two to three rows of 'Wichita' per row of 'Western Schley' (2:1 to 3:1).

INFLUENCE OF ORCHARD THINNING. In-shell nut yields of both cultivars substantially fluctuated (age 16 and 17 years in Fig. 3) before orchard thinning. Compared with previous season yields, in-shell production the crop year subsequent to orchard thinning $(50 \%$ of trees removed by removing alternating diagonal tree rows) declined to $\approx 83 \%$ for 'Wichita' and 50\% for 'Western Schley'; yet, yields were greater than the previous low in the alternate bearing cycle (at age 16 years). The impact of orchard thinning on 'Wichita' was less that that of 'Western Schley'. These data support the principal that, at least for 'Wichita', yield loss from removing trees is favorably disproportional to the number of trees removed $(50 \%$ of trees were removed, but yield was $80 \%$ of pre-removal level). The reduction was directly proportional ( $50 \%$ reduction versus $50 \%$ removed) for 'Western Schley'. This is evidence that 'Wichita' may possess greater ability to rapidly convert additional orchard environmental resources (sunlight, water, etc.) into marketable nut yield than 'Western Schley'. This conclusion tends to be confirmed by the same response being duplicated after the second phase of tree removal (alternating main rows removed), in which 'Wichita' yields (at age 20 years) were greater than that of the previous 2 years whereas 'Western Schley' yields were very low. The intensity of alternate bearing (I) during the years after orchard thinning was much

Fig. 3. In-shell pecan nut yields after orchard thinning, via tree removal (OT), compared with discrete canopy hedge pruning on a 2 -year cycle plus topping on a 2 -year cycle (DCHP / 2 $+\mathrm{T} / 2$ ) for 'Wichita' (A) and 'Western Schley' (B). Prethinning yields are noted for orchard ages of 16 and 17 years. The first thinning $(50 \%$ of trees removed on the diagonal) was completed between age 17 and 18 years; whereas the second thinning cycle (50\% of remaining trees removed by removing alternating rows) was between ages 19 and 20 years. Thus, the number of trees per unit area in the OT treatment from age 20 to 25 years was $25 \%$ that of the DCHP $/ 2+$ $\mathrm{T} / 2$ treatment. The $\mathrm{OT}$ and DCHP/ $2+\mathrm{T} / 2$ treatments were imposed the dormant season between age 17 and 18 years; $1 \mathrm{lb} /$ acre $=1.12 \mathrm{~kg} \cdot \mathrm{ha}^{-1}$.
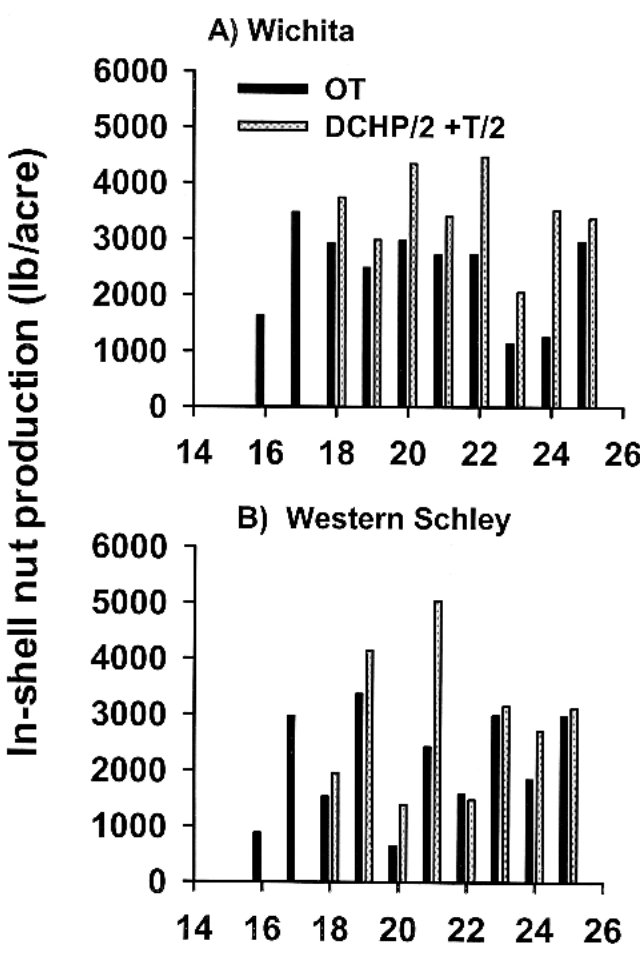

Orchard age (years) 

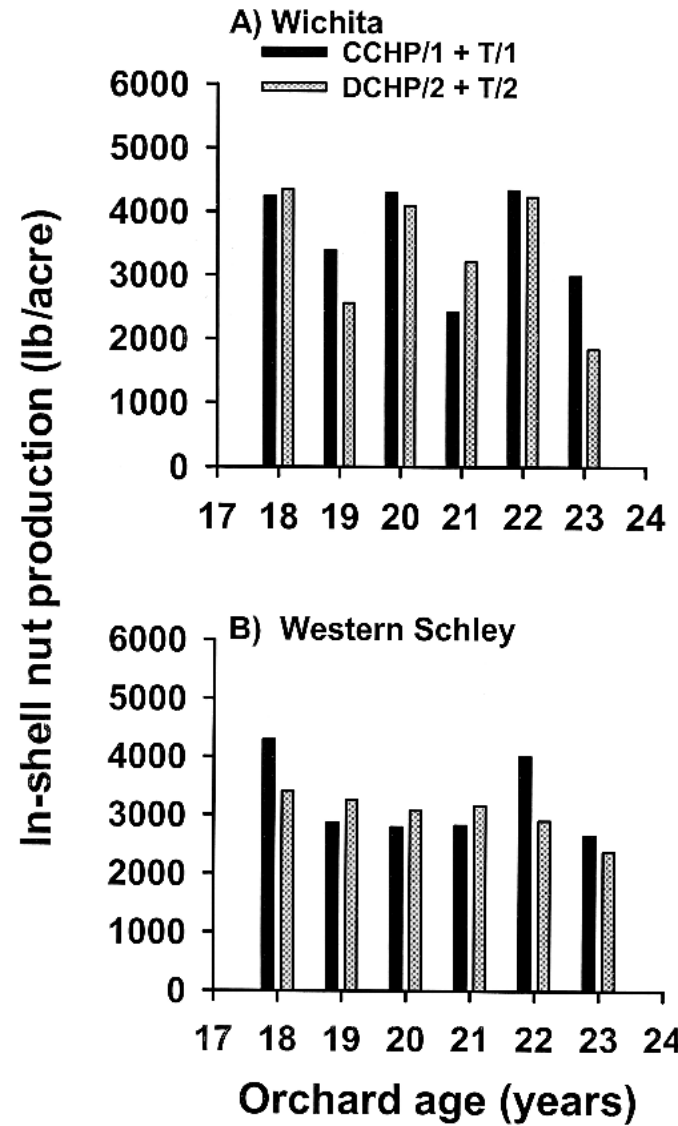

Fig. 4. Influence of two different hedge pruning strategies on absolute and relative in-shell yields of 'Wichita' and 'Western Schley' pecans. The discrete canopy hedge produces a $22-\mathrm{ft}(6.7-\mathrm{m})$ wide square-like tree with a pyramidal top peaking at $33 \mathrm{ft}(10.1 \mathrm{~m})$, and is a 2-year cycle. The continuous canopy hedgerow produces an $8 \times$ $30-\mathrm{ft}(2.4 \times 9.1-\mathrm{m})$ quasi-hedgerow that is cut at $33 \mathrm{ft}$ high, and is a 1 -year pruning cycle. Data points represent $\approx 15$ acres $(6.1$ ha) of trees over a 6-year period. 1 $\mathrm{lb} / \mathrm{acre}=1.12 \mathrm{~kg} \cdot \mathrm{ha}^{-1}$.

greater for 'Western Schley' than for 'Wichita'.

A comparison of $\mathrm{OT}$ and $\mathrm{DCHP} / 2+\mathrm{T} / 2$ treatments indicates that, in any given year, in-shell yield from OT was almost always less than $\mathrm{DCHP} / 2+\mathrm{T} / 2$ (Fig. 3). This was true for both 'Wichita' and 'Western Schley' (Fig. 3). Main-effect comparisons over the life of the study was such that yield from the OT treatment was much less than that of the $\mathrm{DCHP} / 2+\mathrm{T} / 2$ treatment (at $P=0.05$ ). There were no orchard management $\times$ cultivar interactions (at $P=0.10)$. Average annual yield and $\mathbf{I}$ for the four treatments over the life of the study were 'Wichita'+OT = $2345 \mathrm{lb} /$ acre $\left(2628.3 \mathrm{~kg} \cdot \mathrm{ha}^{-1}\right)$ and I $=0.26$; 'Wichita' + DCHP $/ 2+\mathrm{T} / 2$ $=2996 \mathrm{lb} /$ acre $\left(3358.0 \mathrm{~kg} \cdot \mathrm{ha}^{-1}\right)$ and I $=0.21$; 'Western Schley'+OT $=2077$ $\mathrm{lb} /$ acre $\left(2328.0 \mathrm{~kg} \cdot \mathrm{ha}^{-1}\right)$ and $\mathrm{I}=0.36$; and 'Western Schley'+DCHP / $2+\mathrm{T} / 2$ $=2338 \mathrm{lb} /$ acre $\left(2620.5 \mathrm{~kg} \cdot \mathrm{ha}^{-1}\right)$ and $\mathrm{I}=0.36$. Thus, the hedging strategy produced in-shell yields that were 144\% of the orchard thinning strategy for 'Wichita' and 113\% for 'Western Schley'. Hedging reduced I for 'Wichita', but had no influence on I for 'Western Schley'.

Comparison OF YIELDS BETWEen DISCRETE AND CONTINUOUS HEDGE PRUNING SYSTEMS. In-shell yield for both 'Wichita' (Fig. 4A) and 'Western Schley' (Fig. 4B) was relatively stable for 6 years when subjected to either discrete or continuous hedge pruning treatments. Alternate bearing index was 0.12 for the 'Wichita' CCHP $/ 1+\mathrm{T} / 1$ treatment and 0.34 for the 'Wichita'

Table 2. Yield and nut quality characteristics of 'Wichita' and 'Western Schley' pecans managed via either DCHP $/ 2+\mathrm{T} / 2$ or $\mathrm{CCHP} / 1+\mathrm{T} / 1$ pruning strategies. ${ }^{\mathrm{z}}$

\begin{tabular}{|c|c|c|c|c|c|c|c|}
\hline Treatment & $\begin{array}{l}\text { In-shell } \\
\text { yield } \\
\text { (lb/acre) }\end{array}$ & $\begin{array}{l}\text { Alternate } \\
\text { bearing } \\
\text { index } \\
(\mathrm{I})\end{array}$ & $\begin{array}{c}\text { Shellout }^{\mathrm{x}} \\
(\%)\end{array}$ & $\begin{array}{c}\text { Total } \\
\text { kernel } \\
\text { yield } \\
\text { (lb/acre) }\end{array}$ & $\begin{array}{c}\text { Premium }^{\mathrm{w}} \\
\text { kernel } \\
\text { yield } \\
(\%)\end{array}$ & $\begin{array}{c}\text { Choicev }^{\mathrm{v}} \\
\text { kernel } \\
\text { yield } \\
(\%)\end{array}$ & $\begin{array}{c}\text { Market }^{\mathrm{u}} \\
\text { kernel } \\
\text { yield } \\
(\mathrm{lb} / \text { acre })\end{array}$ \\
\hline 'Wichita'; DCHP / $2+\mathrm{T} / 2$ & $3380 \mathrm{a}$ & 0.34 & 61.7 & 2085 & 78.3 & 16.8 & 1,669 \\
\hline 'Wichita'; CCHP/1+T/1 & $3607 \mathrm{a}$ & 0.12 & 62.2 & 2243 & 76.5 & 16.4 & 1,967 \\
\hline 'Western Schley'; DCHP / $2+\mathrm{T} / 2$ & $3022 \mathrm{a}$ & 0.12 & 56.4 & 1704 & 51.9 & 39.8 & 1,317 \\
\hline 'Western Schley'; CCHP/1+T/1 & $3234 \mathrm{a}$ & 0.12 & 57.5 & 1860 & 55.4 & 35.5 & 1,727 \\
\hline
\end{tabular}

${ }^{2} \mathrm{DCHP} / 2+\mathrm{T} / 2=$ Discrete canopy pruning on a 2 -year cycle; CCHP $/ 1+\mathrm{T} / 1=$ Continuous canopy pruning on a 1 -year cycle. Data are for a 6 -year period. In-shell means among the four treatments were not statistically different at the $P=0.10 \mathrm{level} ; 1 \mathrm{lb} / \mathrm{acre}=1.12 \mathrm{~kg} \cdot \mathrm{ha}^{-1}$.

yndex ranging from 0 to $\mathrm{l}$ that quantifies the intensity of alternate bearing. $\mathrm{O}=$ no yield difference from one year to the next, $\mathrm{l}=\mathrm{no}$ yield in alternating years

${ }^{x}$ Percentage of nut comprised of kernel. Typically, for the cultivars, $<52 \%=$ low, $52 \%$ to $58 \%=$ medium, $>58 \%=$ high

wercentage of kernel crop grading premium (i.e., highest quality).

vercentage of kernel up grading choice (i.e., second highest quality grade).

"Those nuts that are readily marketed.

Table 3. Influence of row orientation on yield and nut quality characteristics of continuous canopy pruned 'Wichita' and 'Western Schley' pecan trees $(\mathrm{CCHP} / 1+\mathrm{T} / 1)$ on a 1 -year pruning cycle. ${ }^{\mathrm{z}}$

\begin{tabular}{|c|c|c|c|c|c|c|}
\hline Cultivar & $\begin{array}{c}\text { Row }^{\mathrm{y}} \\
\text { orientation }\end{array}$ & $\begin{array}{c}\text { In-shell }^{\mathrm{x}} \\
\text { yield } \\
\text { (lb/acre) }\end{array}$ & $\begin{array}{c}\text { Shellout }^{\mathrm{w}} \\
(\%)\end{array}$ & $\begin{array}{c}\text { Premium }^{\mathrm{v}} \\
\text { kernel } \\
(\%)\end{array}$ & $\begin{array}{c}\text { Choice }^{\mathrm{v}} \\
\text { kernel } \\
(\%)\end{array}$ & $\begin{array}{c}\text { Nuts }^{u} / \\
\text { lb } \\
\text { (no.) }\end{array}$ \\
\hline Wichita & $\mathrm{N}-\mathrm{S}$ & $3121 \mathrm{~b}$ & 61.7 & 78.7 & 17.0 & 51 \\
\hline Wichita & $\mathrm{E}-\mathrm{W}$ & $1973 \mathrm{a}$ & 61.2 & 85.4 & 12.5 & 49 \\
\hline Western Schley & $\mathrm{N}-\mathrm{S}$ & $2536 \mathrm{~b}$ & 55.9 & 55.9 & 40.5 & 65 \\
\hline Western Schley & E-W & $1459 \mathrm{a}$ & 57.9 & 55.4 & 39.5 & 64 \\
\hline
\end{tabular}

${ }^{\mathrm{z}}$ Canopies hedge pruned to about $3.5 \mathrm{ft}(1.07 \mathrm{~m})$ from row center and pruned at $4 \mathrm{ft}(1.2 \mathrm{~m})$ in subsequent years. $1 \mathrm{lb} / \mathrm{acre}=1.12 \mathrm{~kg} \cdot \mathrm{ha}{ }^{-1}$.

'Rows running either north-south $(\mathrm{N}-\mathrm{S})$ or east-west $(\mathrm{E}-\mathrm{W})$.

${ }^{x}$ Means followed by different letters are statistically different at $P=0.05$ with main effects and interactions tested using resampling techniques using bootstrapping with hypothesis testing at 10,000 iterations for determining confidence limits of $P=0.05$ for main effects and $P=0.10$ for interactions.

wercentage kernel.

"Percentage of kernels rating a premium or choice grade.

" 1 nut $/ \mathrm{lb}=2.2$ nuts $/ \mathrm{kg}$. 


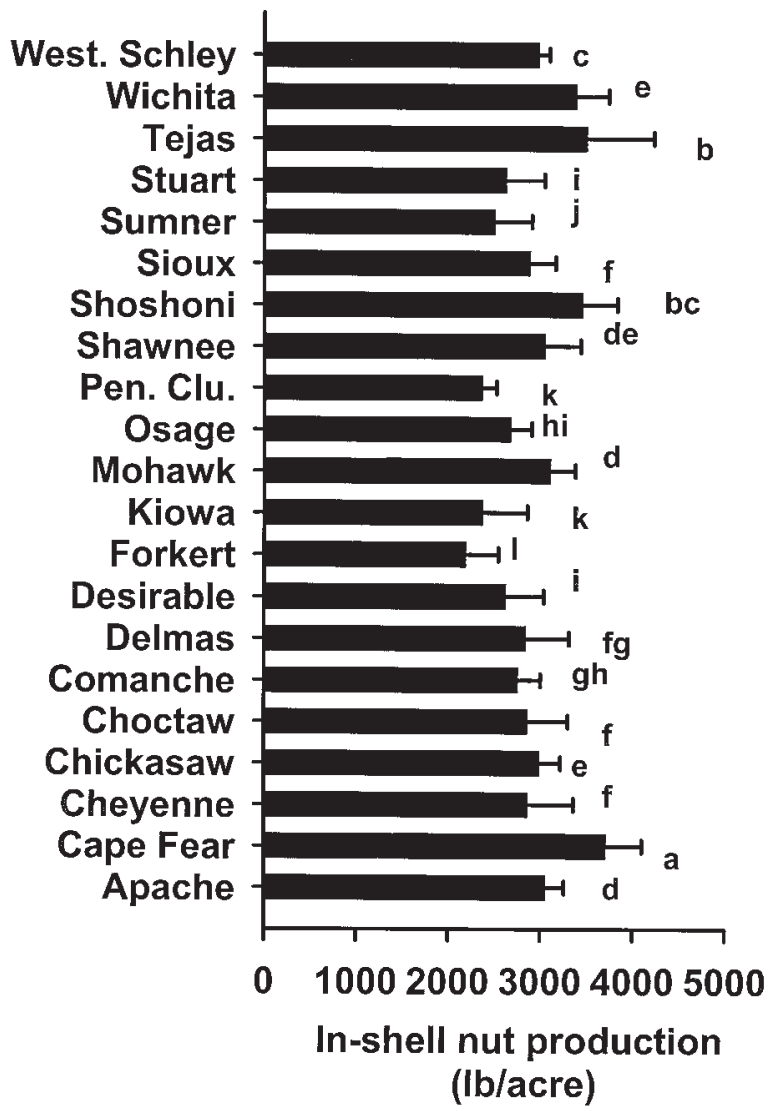

Fig. 5. Relative annual in-shell yields of several pecan cultivars managed under a discrete canopy hedge pruning strategy (as described in Fig. 4). Bars represent standard errors. Cultivars means followed by different letters are statistically different at $P=0.05$. 1 $\mathrm{lb} /$ acre $=1.12 \mathrm{~kg} \cdot \mathrm{ha}^{-1}$.

$\mathrm{DCHP} / 2+\mathrm{T} / 2$ treatment (Table 2 ). For 'Western Schley' it was 0.12 for both $\mathrm{CCHP} / 1+\mathrm{T} / 1$ and $\mathrm{DCHP} /$ $2+\mathrm{T} / 2$ treatments. Mean in-shell production for the test period, for 'Western Schley', was $3234 \mathrm{lb} /$ acre $\left(3624.8 \mathrm{~kg} \cdot \mathrm{ha}^{-1}\right)$ for the CCHP-1 $+\mathrm{T}-1$ treatment and $3022 \mathrm{lb} / \mathrm{acre}$ $\left(3387.1 \mathrm{~kg} \cdot \mathrm{ha}^{-1}\right)$ for the $\mathrm{DCHP} / 2$ $+\mathrm{T} / 2$ treatment; whereas, production for 'Wichita' was $3607 \mathrm{lb} /$ acre $\left(4042.8 \mathrm{~kg} \cdot \mathrm{ha}^{-1}\right)$ for CCHP $/ \mathrm{l}+\mathrm{T} / \mathrm{l}$ and $3380 \mathrm{lb} /$ acre $\left(3788.4 \mathrm{~kg} \cdot \mathrm{ha}^{-1}\right)$ for $\mathrm{DCHP} / 2+\mathrm{T} / 2$. Mean in-shell nut yields were not statistically different for the two hedge-pruning treatments $(P$ $=0.10)$. There was no interaction between pruning method and cultivar at $P=0.10$. However, in absolute terms, in-shell production for $\mathrm{CCHP} / \mathrm{l}+$ $\mathrm{T} / 1$ was $107 \%$ of $\mathrm{DCHP} / 2+\mathrm{T} / 2$ for 'Western Schley' and CCHP $/ 1+$ $\mathrm{T} / 1$ was $107 \%$ of $\mathrm{DCHP} / 2+\mathrm{T} / 2$ for 'Wichita'-resulting in the CCHP/1 $+\mathrm{T} / \mathrm{l}$ pruning strategy being judged (but not significantly different) as being slightly more profitable in this particular orchard operation.

An advantage of the $\mathrm{CCHP} / 1+\mathrm{T} / 1$ hedgetype pruning treatment appears to be that of increased nutmeat quality. Both cultivars appear to have exhibited higher nutmeat quality characteristics (greater shellout percentage, total kernel yield, premium and choice kernel yields, and market kernel yield) than nuts from the DCHP $/ 2$ $+\mathrm{T} / 2$ treatment (Table $2)$. Thus, based on $\approx 15$ acres (6.1 ha) of trees for each of the four above described treatments, it is apparent that for 'Wichita' and 'Western Schley', marketable kernels per acre for the CCHP/1 + $\mathrm{T} / 1$ treatment was most likely slightly better than that of the DCHP $/ 2+\mathrm{T} / 2$ treatment (data did not lend itself to statistical analysis).

These data indicate that quasicontinuous canopy pruning to within $\approx 4 \mathrm{ft}$ of the tree center is useful for producing high yielding hedgerow-like canopies that exhibit reduced alternate bearing. Additionally, this method appears likely to out yield any other known hedge pruning strategy observed to date.

It is noteworthy that the age of the vegetative regrowth being cut substantially influences pruning cost, hence imparting an advantage to the $\mathrm{CCHP} / \mathrm{l}+\mathrm{T} / \mathrm{l}$ treatment. Hedging cost is usually based on hourly fees. The more trees hedged per hour, the lower the cost. In the above study, pruning of 1-year-old shoots associated with the $\mathrm{CCHP} / \mathrm{l}+\mathrm{T} / \mathrm{l}$ treatment was much easier and faster than the 2-yearold shoots of the $\mathrm{DCHP} / 2$ $+\mathrm{T} / 2$ treatment (because of the much larger crosssectional area and greater lignification of 2-year-old shoots). This is therefore an important factor potentially favoring short-cycle pruning.

Unit area nut yield from pecan farming operations is typically lower than that of other North American tree-nut crops [persian walnut (Juglans regia), almond (Prunus amygdalus), and pistachio (Pistacia vera)]. For example, average unit area in-shell persian walnut yields (in California) are typically $\approx 2760 \mathrm{lb} /$ acre $(3093.5$ $\mathrm{kg} \cdot \mathrm{ha}^{-1}$ ) with a maximum of $\approx 6400$ $\mathrm{lb} /$ acre $\left(7173.3 \mathrm{~kg} \cdot \mathrm{ha}^{-1}\right)$ (S. Sibbett and W. Olsen, unpublished). Similarly, per personal communication (S. Sibbett and W. Olsen, unpublished data) almond yields are $\approx 1773 \mathrm{lb} /$ acre (1987.2 $\mathrm{kg} \cdot \mathrm{ha}^{-1}$ ) of meats, with a maximum of $\approx 4000 \mathrm{lb} /$ acre $(4483.3$ $\left.\mathrm{kg} \cdot \mathrm{ha}^{-1}\right)$. Pistachio in-shell yields are $\approx 2260 \mathrm{lb} /$ acre $\left(2533.1 \mathrm{~kg} \cdot \mathrm{ha}^{-1}\right)$, with a maximum of $\approx 5000 \mathrm{lb} /$ acre $(5604.2$ $\left.\mathrm{kg} \cdot \mathrm{ha}^{-1}\right)$. By contrast, average in-shell pecan yields in the southeastern U.S. are $\approx 800$ to $1,500 \mathrm{lb} /$ acre $(896.7$ to $\left.168 \mathrm{l} .2 \mathrm{~kg} \cdot \mathrm{ha}^{-1}\right)$ and 1800 to $2600 \mathrm{lb} /$ acre $\left(2017.5\right.$ to $\left.2914.2 \mathrm{~kg} \cdot \mathrm{ha}^{-1}\right)$ in the southwestern U.S. Maximum per annum in-shell pecan yield in commercial orchard operations in the U.S. is $\approx 4000$ $\mathrm{lb} / \mathrm{acre}$, but is not sustainable. The relatively low unit area yield of pecan, as compared to other tree-nut crops, is often viewed as a factor limiting its

Fig. 6. Relative alternate bearing index (I) values of pecan cultivars managed under a discrete canopy hedge pruning strategy (as described in Figs. 4 and 5).

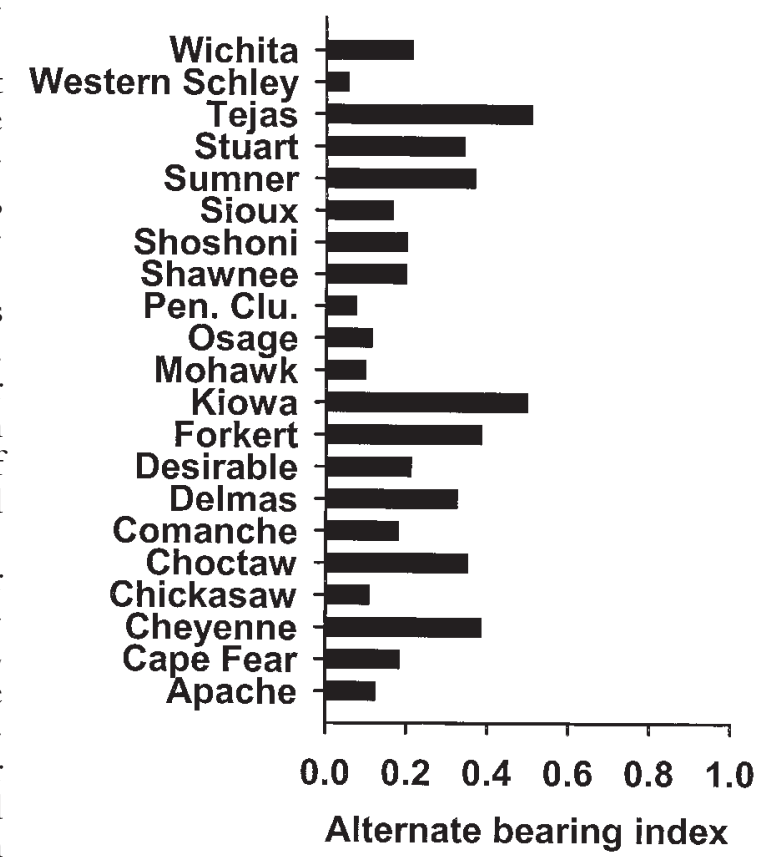


Table 4. Comparative nut yield and quality characteristics of pecan cultivars managed as a discrete canopy hedge with topping (i.e., DCHP $/ 2+\mathrm{T} / 2)$. Data are from 1 acre $(0.4 \mathrm{ha})^{\mathrm{z}}$ of trees per cultivar when trees were ages 22 to 27 years.

\begin{tabular}{|c|c|c|c|c|c|c|c|c|c|c|}
\hline Cultivar & $\begin{array}{c}\text { In-shell } \\
\text { yield } \\
\text { (lb/acre) }\end{array}$ & $\begin{array}{c}\text { Total } \\
\text { kernel } \\
\text { yield } \\
\text { (lb/acre) }\end{array}$ & $\begin{array}{c}\text { Premium }^{\mathrm{y}} \\
\text { kernel } \\
\text { yield } \\
(\mathrm{lb} / \text { acre })\end{array}$ & $\begin{array}{c}\text { Choice } \\
\text { kernel } \\
\text { yield } \\
\text { (lb/acre) }\end{array}$ & $\begin{array}{c}\text { Market }^{\mathrm{x}} \\
\text { kernel } \\
\text { yield } \\
\text { (lb/acre) }\end{array}$ & $\begin{array}{c}\text { Shellout } \\
(\%)\end{array}$ & $\begin{array}{c}\text { Premium }^{\mathrm{v}} \\
\text { kernel } \\
(\%)\end{array}$ & $\begin{array}{c}\text { Choice } \\
\text { kernel } \\
(\%)\end{array}$ & $\begin{array}{c}\text { Other }^{\mathrm{u}} \\
\text { kernel } \\
(\%)\end{array}$ & $\begin{array}{c}\text { Nuts }^{v} / \\
\text { lb } \\
\text { (no.) }\end{array}$ \\
\hline Apache & $2913 \mathrm{~d}$ & 1658 & 1413 & 203 & 1616 & 56.9 & 85 & 12 & 3 & 55 \\
\hline Cape Fear & 3488 a & 1899 & 1276 & 552 & 1828 & 54.4 & 67 & 29 & 4 & 55 \\
\hline Cheyenne & $2609 \mathrm{f}$ & 1376 & 827 & 437 & 1264 & 52.7 & 60 & 32 & 8 & 69 \\
\hline Chickasaw & $2763 \mathrm{e}$ & 1399 & 719 & 547 & 1266 & 50.6 & 51 & 39 & 10 & 69 \\
\hline Choctaw & $2821 \mathrm{f}$ & 1580 & 1126 & 353 & 1478 & 56.0 & 71 & 22 & 7 & 48 \\
\hline Comanche & $2553 \mathrm{gh}$ & 1282 & 972 & 188 & 1160 & 50.2 & 76 & 15 & 9 & 43 \\
\hline Delmas & $2942 \mathrm{fg}$ & 1361 & 662 & 560 & 1222 & 46.3 & 49 & 41 & 10 & 54 \\
\hline Desirable & $2389 \mathrm{i}$ & 1292 & 893 & 345 & 1238 & 54.1 & 69 & 27 & 4 & 49 \\
\hline Forkert & 22001 & 1331 & 960 & 333 & 1292 & 60.5 & 72 & 25 & 3 & 54 \\
\hline Kiowa & $2179 \mathrm{k}$ & 1270 & 937 & 296 & 1232 & 58.3 & 74 & 23 & 3 & 50 \\
\hline Mohawk & $2904 d$ & 1623 & 591 & 715 & 1305 & 55.9 & 36 & 44 & 20 & 45 \\
\hline Osage & $2310 \mathrm{hi}$ & 1229 & 822 & 282 & 1105 & 53.2 & 67 & 23 & 10 & 78 \\
\hline Pen. Cluster & 2477 k & 1243 & 935 & 291 & 1226 & 50.2 & 76 & 23 & 1 & 48 \\
\hline Shawnee & 3007 de & 1515 & 600 & 662 & 1262 & 50.4 & 40 & 44 & 16 & 60 \\
\hline Shoshoni & $3360 \mathrm{bc}$ & 1832 & 1120 & 621 & 1740 & 54.5 & 61 & 34 & 5 & 56 \\
\hline Sioux & $2750 \mathrm{f}$ & 1655 & 1002 & 506 & 1508 & 60.2 & 61 & 31 & 8 & 74 \\
\hline Sumner & $2542 j$ & 1399 & 936 & 429 & 1366 & 55.0 & 67 & 31 & 2 & 58 \\
\hline Stuart & $2600 \mathrm{i}$ & 1287 & 806 & 465 & 1271 & 49.5 & 63 & 36 & 1 & 48 \\
\hline Tejas & $3626 a$ & 1921 & 1383 & 468 & 1852 & 53.0 & 72 & 24 & 4 & 72 \\
\hline Wichita & $3355 \mathrm{c}$ & 2071 & 1617 & 346 & 1963 & 61.7 & 78 & 17 & 5 & 50 \\
\hline Western Schley & $2781 \mathrm{e}$ & 1572 & 822 & 618 & 1440 & 56.5 & 52 & 39 & 9 & 65 \\
\hline
\end{tabular}

${ }^{2}$ Trees spaced on a $33 \times 33-\mathrm{ft}(10.1-\mathrm{m})$ square and with opposite sides hedged at $11 \mathrm{ft}(3.4 \mathrm{~m})$ every 2 years. Trees are also topped on opposite sides on a 2 -year cycle. Mean in-shell yields differ among cultivars (via resampling-bootstrap multiple range test) if means are followed by different letters $(P=0.05)$. $1 \mathrm{lb} / \mathrm{acre}=1.12 \mathrm{~kg}$.ha ${ }^{-1}$.

ypremium is the highest grade.

xThose nut meats that are easily marketed.

wPercentage of nut consisting of kernel. Typically $<52 \%=$ low; $52 \%$ to $58 \%=$ medium; $>58 \%=$ high.

'Percentage of kernel crop grading as premium quality kernels.

"Grade consisting of amber and lesser grades.

${ }^{v} \mathrm{l}$ nut $/ \mathrm{lb}=2.2$ nuts $/ \mathrm{kg}$.

popularity among certain farmers. In the present study, one-time maximum block yields reached $7555 \mathrm{lb} /$ acre, with sustained large-block yields of $\approx 3400$ $\mathrm{lb} /$ acre $\left(3810.8 \mathrm{~kg} \cdot \mathrm{ha}^{-1}\right)[2098 \mathrm{lb}$ of kernels/acre $\left.\left(235 \mathrm{l} .5 \mathrm{~kg} \cdot \mathrm{ha}^{-1}\right)\right]$. Thus, certain hedge pruning strategies appear to possess potential for elevating unit area yield of pecan to a level comparable to that of other tree-nut crops.

INFLUENCE OF ROW DIRECTION ON NUT YIELD FROM HEDGEROW TREES. Altering row orientation of the $\mathrm{CCHP} / \mathrm{l}+$ $\mathrm{T} / \mathrm{l}$ trees to run either $\mathrm{N}-\mathrm{S}$ or $\mathrm{E}-\mathrm{W}$ influenced yield characteristics such that in-shell nut yield was greatest for $\mathrm{N}-\mathrm{S}$ rows $(P=0.05$; Table 3$)$. There was no cultivar-orientation interaction $(P=0.10)$. In-shell nut yield for $\mathrm{N}-\mathrm{S}$ 'Wichita' was $158 \%$ that of $\mathrm{E}-\mathrm{W}$ trees and N-S 'Western Schley' was $174 \%$ that of $\mathrm{E}-\mathrm{W}$ trees, indicating an advantage for $\mathrm{N}-\mathrm{S}$ orientation at this latitude. There were no orientation linked treatment differences with kernel and meat quality characteristics [i.e., crackout percentage (kernel percentage), kernel grades, or nut size], thus the influence of row orientation on yield appears to be mostly influenced by number of fruit per tree rather than via fruit quality. This advantage of $\mathrm{N}-\mathrm{S}$ orientation was also noted in hedgerow plantings of pear [Pyrus pyrifolia (Khemira et al., 1993)], apple [Malus spp. (Palmer, 1989)], and vineyards [Vitis vinifera (Smart, 1973)].

Yield ResPonse of Cultivars to HEDGE PRUNING. Eight years of production from 21 cultivars managed via $\mathrm{DCHP} / 2+\mathrm{T} / 2$ pruning is illustrated in Fig. 5. The resampling-bootstrap multiple range testing technique identified statistical differences among cultivars. Maximum annual mean inshell yield was from 'Cape Fear' [3488 lb/acre (3909.5 kg.ha $\left.{ }^{-1}\right)$ ], 'Tejas' [3626 lb/acre (4064.1 kg.ha-1)], 'Shoshoni' [3360 lb/acre (3766.0 $\left.\left.\mathrm{kg} \cdot \mathrm{ha}^{-1}\right)\right]$, and 'Wichita' [3355 lb/acre $\left.\left(3760.4 \mathrm{~kg} \cdot \mathrm{ha}^{-1}\right)\right]$. The lowest yielding cultivar ('Forkert') averaged $2200 \mathrm{lb}$ / acre $\left(2465.8 \mathrm{~kg} \cdot \mathrm{ha}^{-1}\right)$, which by most commercial orchard standards is excellent yield. All 21 cultivars exhibited relatively high yields when receiving the $\mathrm{DCHP} / 2+\mathrm{T} / 2$ pruning treatment. These sustainable yields were higher than when managed at other geographical locations with little or no canopy pruning. Even 'Desirable' and 'Stuart', two cultivars noted for relatively low production $[<1500$ to $2000 \mathrm{lb} /$ acre (1681.2 to 2241.7 $\left.\mathrm{kg} \cdot \mathrm{ha}^{-1}\right)$ ] averaged 2389 and 2600 $\mathrm{lb} /$ acre $\left(2677.7\right.$ to $\left.2914.2 \mathrm{~kg} \cdot \mathrm{ha}^{-1}\right)$, respectively. Worley (1985) observed that 'Desirable' trees hedged as a discrete canopy, on a 4-year cycle (one side per year) plus topping every fifth year at 20 to $30 \mathrm{ft}$, reduced in-shell nut yields to $\approx 78 \%$ of nonpruned trees (over 8 years). It was therefore concluded that hedging did not appear to be suitable for cultivars grown in the southeastern U.S. By contrast, most cultivars in the present hedge pruning study are also grown in the southeastern U.S., and produced relatively high yields. This contrasting response may be due to several factors. These include l) possibly lower sunlight levels in the southeastern U.S.; 2) differences in length of the pruning cycle ( 2 versus 4 years); 
and 3) differences in topping height (20 to 30 versus $33 \mathrm{ft}$ ).

The alternate bearing intensity of these cultivars was generally relatively low (Fig. 6). I values $<0.25$ reflect low alternate bearing. The DCHP $/ 2$ $+\mathrm{T} / 2$ pruning treatment produced relatively low levels of alternate bearing for 'Wichita', 'Western Schley', 'Sioux', 'Shoshoni', 'Shawnee', 'Pensacola cluster', 'Osage', 'Mohawk', 'Desirable', 'Comanche', 'Chickasaw', 'Cape Fear', and 'Apache'. It is typical for all of these cultivars (except for 'Desirable') to exhibit much higher levels of I under nonpruned conditions (Conner and Worley, 2000). It is noteworthy that I of 'Tejas' and 'Kiowa' was relatively high ( 0.58 and 0.56 , respectively), even though crop load was being reduced via hedge pruning.

These 21 cultivars markedly differed in kernel quality characteristics (Table 4). While each trait noted in Table 4 influences monetary value, it is the percentage of premium quality kernels and the marketable yield per unit area that are most important. In the case of Premium kernels, it was 'Apache' (85\%), 'Wichita' (78\%), 'Comanche' $(76 \%)$, and 'Pensacola Cluster' (76\%) that were highest. Conversely, the lowest were 'Mohawk' (36\%), 'Shawnee' (40\%), 'Delmas' (49\%), and 'Chickasaw' (51\%).

Market yield is that poundage of kernels per unit area of orchard that is in the premium plus choice kernel quality classes (excluding amber and other). Market yield of kernels was greatest with 'Wichita' [1963 lb/acre, $\left.\left(2200.2 \mathrm{~kg} \cdot \mathrm{ha}^{-1}\right)\right]$ Tejas' [1852 lb/acre $\left.\left(2075.8 \mathrm{~kg} \cdot \mathrm{ha}^{-1}\right)\right]$, 'Cape Fear' [1828 $\mathrm{lb} / \mathrm{acre}\left(2048.9 \mathrm{~kg} \cdot \mathrm{ha}^{-1}\right)$ ], and 'Shoshoni' $\left[1740 \mathrm{lb} /\right.$ acre $\left.\left(1950.2 \mathrm{~kg} \cdot \mathrm{ha}^{-1}\right)\right]$. Conversely, the lowest market yield was with 'Osage' [1105 lb/acre (1238.5 $\left.\mathrm{kg} \cdot \mathrm{ha}^{-1}\right)$ ], 'Comanche' [1160 lb/acre (1300.2 kg.ha-1)], 'Delmas' [1222 lb/acre (1369.7 kg.ha-1)], 'Kiowa' [1232 lb/acre $\left.\left(1380.9 \mathrm{~kg} \cdot \mathrm{ha}^{-1}\right)\right]$, and 'Desirable' [1238 lb/acre (1387.6 $\left.\left.\mathrm{kg} \cdot \mathrm{ha}^{-1}\right)\right]$. There are many factors (cost of production, market niche, time of ripening, shell or kernel size, meat color quality grade, and market price) that contribute to a cultivar's profitability. However, under the conditions of this study, 'Wichita' was most profitable. 'Wichita' possessed high average in-shell yields [3355 lb/acre $\left.\left(3760.4 \mathrm{~kg} \cdot \mathrm{ha}^{-1}\right)\right]$, high shellout percentage (61.7\%), high percentage of premium kernels (78\%), and high marketable kernel yields [1963 lb/acre $\left.\left(2200.2 \mathrm{~kg} \cdot \mathrm{ha}^{-1}\right)\right]$.

\section{Conclusion}

These data provide strong evidence that many commercial pecan cultivars, especially 'Wichita' and 'Western Schley', can be highly productive using a discrete canopy hedge pruning strategy that utilizes short duration pruning cycles. Not only are sustained in-shell and marketable nut meat yields likely the highest ever produced by commercial orchards, the strategy also reduces alternate bearing. This moderation of alternate bearing offers a new tool to assist orchard managers in alleviating the economically most important biological problem of pecan.

Results also indicate that maximum yield from commercial pecan orchard operations may well be derived from properly spaced hedgerow-like plantings in which $\mathrm{N}-\mathrm{S}$ hedgerows are maintained relatively narrow so as to maximize the volume of fruiting canopy per unit area of orchard. This strategy worked well for 'Wichita' and 'Western Schley', and is likely to work for many other cultivars. However, it should be viewed cautiously for certain other cultivars because of the possibility of adverse effects on fruiting by excess vigor and shading.

These findings indicate that, under certain orchard situations, mechanized pruning offers a viable alternative to the conventional pecan production paradigm and additionally provides a practical means of enabling control of tree size and orchard crowding. The applicability of mechanized hedge pruning to climatic regions possessing greater exposure to disease and arthropod pests will require further research.

\section{Literature cited}

Amling, H.J. and K.A. Amling. 1983. Physiological differentiation of pistillate flowers of pecan and cold requirements for their initiation. J. Amer. Soc. Hort. Sci. 108:195-198.

Amling, H.J., K.A. Marcus, J.E. Barnett, and N.R. McDaniel. 1975. Nut quality of selected pecan varieties grown in south Alabama. Auburn Univ. Agr. Expt. Sta. Circ. 225 .

Blank, S., C. Seiter, and P. Bruce. 2001. Resampling stats in Excel. $2^{\text {nd }}$ ed. Resampling Stat., Inc., Arlington, Va.

Conner, P.J. and R.E. Worley. 2000. Alternate bearing intensity of pecan cultivars.
HortScience 35:1067-1069.

Khemira, H., P.B. Lombard, D. Sugar, and A.N. Azarenko. 1993. Hedgerow orientation affects canopy exposure, flowering, and fruiting of 'Anjou' pear trees. HortScience 28(10):984-987.

Malstrom, H.L. 1981. Effect of hedge pruning on light penetration, nut production, and nut quality of western pecan trees. Proc. W. Pecan Conf. 15:4-25.

Malstrom, H.L. and R.L. Haller. 1980. Consequences of hedge pruning pecan trees. Proc. Texas Pecan Growers Assn. $58: 52-56$.

Marquard, R.D. 1988. Outcrossing rates in pecan and the potential for increased yields. J. Amer. Soc. Hort. Sci. 113:84-88.

Palmer, J.W. 1989. The effects of row orientation, tree height, time of year and latitude on light interception and distribution in model apple hedgerow canopies. J. Hort. Sci. 64(2):137-145.

Pearce, S.C. and S. Dobersek-Urbanc. 1967. The management of irregularity in growth and cropping. J. Hort. Sci. 42: 295-305

Reilly, C.C. 1996. Shuck decline problems of the southeast and southwest. Proc. W. Pecan Conf. 13:54-61.

Reilly, C.C. and B.W. Wood. 1995. Shuck disorder, A pathologist's view. Proc. 2nd Natl. Pecan Wkshp. 2:76-77.

Smart, R.E. 1973. Sunlight interception by vineyards. Amer. J. Enol. Viticult. 24(4): 141-147.

Smith, M.W. and J.C. Gallott. 1990. Mechanical thinning of pecan fruit. HortScience 25:414-416.

Smith, M.W. and H.A. Hinrichs. 1980. High density pecan plantings in Oklahoma. Pecan Quartly. 14:4-6.

Smith, M.W., W. Reid, B. Carroll, and B. Cheney. 1993. Mechanical fruit thinning influences fruit quality, yield, return fruit set, and cold injury of pecan. HortScience 28:1081-1084.

Sparks, D., W. Reid, and I.E. Yates. 1995. Fruiting stress induces shuck decline and premature germination in pecan. J. Amer. Soc. Hort. Sci. 120:43-53.

Trewartha, G.T. 1968. An introduction to climate. McGraw-Hill, New York.

Wood, B.W. 1995. Relationship of reproductive and vegetative characteristics of pecan to previous season fruit development and post ripening foliation period. J. Amer. Soc. Hort. Sci. 120(4):635-642.

Wood, B.W. 1997. Source of pollen, distance from pollinizer, and time of pol- 
Research Reports

lination affect yields in block-type pecan orchards. HortScience 32:1182-1185.

Wood, B.W. 1999. Discovering the future: A new pecan husbandry paradigm? . Proc. 2nd Natl. Pecan Wkshp. 3:102-105.

Wood, B.W. 2001. Production unit trends and price characteristics within the United States pecan industry. HortTechnology 11(1):110-118

Wood, B.W., P.J. Conner, and R.E. Worley. 2003. Relationship of alternate bearing intensity in pecan to fruit and canopy characteristics. HortScience 38:361-366.

Wood, B.W. and R.D. Marquard. 1992. Estimates of self-pollination in pecan orchards in the southeastern United States. HortScience 27:406-408.

Worley, R.E. 1979a. Pecan yield, quality, nutlet set, and spring growth as a response of time of fall defoliation. J. Amer. Soc. Hort. Sci. 104:192-194.

Worley, R.E. 1979b. Fall defoliation date and seasonal carbohydrate concentration of pecan wood tissues. J. Amer. Soc. Hort. Sci. 104:195-199.

Worley, R.E. 1985. Effects of hedging and selective limb pruning of Elliott, Desirable, and Farley pecan trees under three irrigation regimes. J. Amer. Soc. Hort. Sci. 110(1): $12-16$. 